\title{
The effect of calcium silicate in barley pot experiments
}

\author{
GOTFRED UHLEN \\ Agricultural University of Norway, 1432 As- $N L H$
}

\begin{abstract}
In a greenhouse pot experiment lasting five years, 14 tons per hectare of calcium silicate $(12 \%$ Ca) were compared with an equivalent calcium hydroxide application, $3.2 \mathrm{t} / \mathrm{ha}$, on a loam soil $\left(\mathrm{A}_{\mathrm{A}}\right)$. Also, the experiment included excess liming with $16 \mathrm{t} \mathrm{Ca}(\mathrm{OH})_{2} / \mathrm{ha}$, with and without the addition of the 14 tons of the calcium silicate material. A two year experiment with silicate and lime was conducted on another loam soil $(* \mathrm{~B} s)$.

The silicate application produced higher yields of barley grain and straw; the effect being proportionately higher than that of an equivalent $\mathrm{Ca}(\mathrm{OH})_{2}$ application. Neither a yield depression caused by an excess lime - excess potassium treatment nor a yield reduction due to boron application in the lowlime series could be counteracted by silicate application $($ soil $\rightarrow A$ s). Significant yield increases for silicate and for lime were found in the 4th and 5th years after application, although the effects were reduced compared to the responses during the first 3 years.

The silica content of barley grain and straw increased considerably after silicate application. In the first year, for example, the percent of $\mathrm{SiO}_{2}$ on straw dry matter rose from less than 1 percent to 7 percent. The silica treatments and the large $\mathrm{SiO}_{2}$ uptake, apparently had no direct effects upon the phosphorus, calcium, potassium or the magnesium content of the barley crops, although the silicate seemed to improve the soil phosphorus availability.

In the high-lime series, potassium applications in the first two years of the experimental period roughly doubled the silica content of barley straw and grain, whereas such an effect by the potassium fertilizers was absent in the low-lime series for both soil $(* A)$ and $(* B)$.

After the five year cropping period, lime and silicate were found to have influenced the soil aggregate size distribution percentages, and had markedly improved the water stability of the soil aggregates.
\end{abstract}

\section{Introduction.}

Silicon is a dominant component of many soils, and it is also absorbed in considerable quantities by plants. The element, therefore, has long been a topic of interest and a number of experiments with silicate materials as fertilizers or soil amendments have been conducted. The necessity of silicon for higher plants has been discussed for more than a hundred years.

Several first rate published review articles concerning silicates in plants and its effect upon plant growth are available: FIDANOvSKI (1968), LEWIN and 
Reimann (1969), Jones and HANdreck (1967). A more detailed treatment of silica in soils is given by McKeague and Cline (1963).

Silicon is regarded as being essential for diatoms and seems to be beneficial for gramineous crops like small grain, rice, sugarcane and sudangrass. According to ARnon (1951) an element is not considered essential unless: a) a deficiency makes it impossible for the plant to complete the vegetative or reproductive stage of its life cycle; b) such deficiency is specific to the element in question and can be prevented or corrected only by supplying that element; and c) the element is directly involved in the nutrition of the plant quite apart from its possible effect in correcting some unfavourable microbiological or chemical condition of the soil. The last criteria means that either a cell component contains the element, or the element participates in a biochemical reaction in the plant. Mitsui and ТАКАтон (1963) studying the silicon effect in rice plants found that the first two criteria mentioned above were satisfied by their experiment, whereas a possible role of silicon in higher plant metabolism remains to be found. Silica, however, may not be quite so unique; while the same is also true of potassium. Potassium is known to be an important plant nutrient, but its biochemical effects on plant growth have as yet not been fully clarified.

Considerable interest in silica has arisen in Hawaii, where dramatic yield responses were obtained in sugarcane experiments (AYRES 1966), leading to the use of soluble silicates, especially calcium metasilicate slags, in commercial practice on sugar plantations (PlucknetT 1972). In Japan, large quantities of calcium silicate are used in rice production (D'HOoRE and Coulter 1972).

Silicon deficiency symptoms are described for rice (Mitsui and TAKatoH 1963) and for sugarcane (PLUCKNTET 1972). The symptoms in rice were found to be surprisingly similar to those in horsetail, Equisetum arvense, a plant with a high Si-demand (Lewin and Rermann 1969). These deficiencies could be corrected only by adding silicon.

The total content of silica in most mineral soils is very high. Aluminosilicates and quartz often make up $\mathbf{7 5}$ percent or more of the inorganic material of soils. Nevertheless, some laterites may contain less than 1 percent silica (ref. in McKeague and Cline 1963). Organic soil may be low in silica, less than one half of one persent $\mathrm{Si}$ is reported in the dry matter of Sphagnum peat (MESHECHOK 1968).

Silica in soil solution and natural waters below pH 9 exists evidently in the form of uncharged monosilicic acid, $\mathrm{Si}(\mathrm{OH})_{4}$ (McKeague and Cline 1963, JoNES and HANDRECK 1967). There is no general relationship between the $\mathrm{pH}$ and the silica concentration in aqueous extracts of different soils. However, there seems to be a minimum which has been variously placed between $\mathrm{pH} 8$ and 9 (McKeague and Cline 1963, Jones and Handreck 1967).

Silica is absorbed by higher plants and diatoms as uncharged monosilicic acid. The uptake of silica is supposed to be passive, and the silica appears to be subsequently distributed throughout the plant by the transpiration stream (Lewin and Reimann 1969, Jones and Handreck 1967). Barber and Shone (1966), however, found silicic acid entering barley roots at a rate two or three times faster than that of water lost in transpiration. Obviously, most plant psecies must have a mechanism for rejecting silica at the root surfaces, because 
the different plant families display a large variation in Si content. Gramineous plants contain from ten to twenty times more silica than do legumes and other dicotyledons (JoNES and HANDRECK 1967). The silica deposited in a number of plant species has been shown to be opal $\left(\mathrm{SiO}_{2} \mathrm{n} \mathrm{H}_{2} \mathrm{O}\right)$ (LANNing et. al. 1958, Jones et. al. 1963) According to Lewin and REImAnn (1969), however, the behaviour of silica in plants is more like that of a silica gel than that of the mineral opal.

In grasses and in the straw of small grains a silica content of $2-\mathbf{5}$ percent of the dry matter is not uncommon. Fidanovski (1968) also reports that silica contents in the range of 7 to 13 percent are found in the husk and the awn of small grains.

It might be noted that a high content of silica in forages may decrease the digestability of the dry matter to the same extent as lignin does (DEINUM and SoEst 1969). Silica urolithiasis may occur in grazing animals. However, the conditions leading to the formation of calculi in the urinary tract have not been precisely defined (JoNEs and HANDRECK 1967).

Silica applications have increased the total yield in a large number of experiments with grasses like small grain, rice and sugarcane. Fiddnovski in his article (1968) cites forty works in the period from 1906 to 1966 in which a positive yield response was recorded in all cases. In trials with dicotyledoneous plants, however, crop response to silicate application seems to be the exception rather than the rule.

In classical Norwegian works (GÅRDER 1930, SEMB 1943), and in a number of works referred to by FIDANOVSKI (1968) and others, silica has increased the solubility of soil phosphorus. In some cases this could explain the positive yield response to silicate application (FIDANovski 1968). A possible substitution of silica for phosphorus in the plants has been investigated. So far, no evidence seems to exist of such substitution effects of Si in plant metabolism (LEwIN and Reimann 1969, Hunter 1965).

An interaction also exists between silicon and manganese, and this interaction may take place within the plants. Application of silica caused reduction in manganese toxicity symptoms without reducing the total absorption of Mn (Williams and Vlamis 1957). Decreased accumulation of manganese, iron, copper and zinc in plant tissues with the addition of $\mathrm{Si}$ is also found (BoweN 1972). In culture medium, silicon has been shown to interfere with the uptake and the utilization of boron (LEwIN and REIMANN 1969).

An increased rate of transpiration has been measured in Si deficient plants (Yoshida et. al. 1959). This fact might help to explain some other effects associated with a silicon deficiency (LEWIN and REIMANn 1969, Fidanovski 1968).

It should be noted in addition that potassium silicate increased the aggregation of some clay minerals and increased the stability of aggregates in soil (Dutr 1947). Increases in the water holding capacity due to the stabilizing of humus components is also reported (FIDANOvSKI 1968). In a Swedish investigation with sodium silicate, however, no effect upon aggregation and aggregate stability of clay soil was detected (BERGGREN 1965). 
To complete the picture it might be added that silica treatments may be expected to increase plant resistance against attacks of fungi and insects (Fidanovski 1968, Jones and Handreck 1967). A possible effect of silica in reducing the lodging liability of cereals cannot be ruled out either (JonEs and HANDRECK 1967).

\section{Methods and materials}

Silicate applications formed a part of the treatments given to barley in pot experiments. In this paper, however, only the effect of silica, including possible interactions with other elements, will be dicsussed. Previous experiments in greenhouses and in the field had shown negative yield responses to potassium on soil "A", depending, however, upon the soil $\mathrm{pH}$. Brown leaf spots, presumably caused by a boron excess, were also experienced in the pot experiments. The general idea of the experiment described in the following pages was to compare calcium silicate with other more common lime materials.

The experiment with soil "An was continued for five years, whereas the soil „B» experiment was run for only two years. Six-litre enamelled pots with $5 \mathrm{~kg}$ dry soil were placed in a greenhouse and watered as required, up to $\mathbf{7 0 - 8 0}$ percent of field capacity.

"Soil "A", a cultivated soil with 25 percent clay, 55 percent silt $(0.002-0.06$ $\mathrm{mm}$ ) and 4-5 percent organic matter, was rather deficient in lime, $\mathrm{pH} \mathbf{5}-\mathbf{5 . 5}$, and only 30 percent base saturation. The cation exchange capacity was $\mathbf{1 5 . 6}$ m.e. per $100 \mathrm{~g}$ dry soil. Soil "B" also had approximately 25 percent clay. However, the silt content was less and the sand content greater than in soil "A". Soil "B" had a humus content of approximately 6 percent and a base saturation percentage of 52 . $(\mathrm{CEC}=20 \mathrm{~m} . \mathrm{e} / 100 \mathrm{~g})$. Both soils can be charaacterized as loams of glacial marine deposits with illite probably as the predominant clay mineral.

The calcium silicate material was prepared from sodium silicate and calcium chloride. The precipitate was washed with destilled water until no $\mathrm{Cl}$ - ions could be detected. Analysis of the material showed 12 percent $\mathrm{Ca}$ and 0.2 percent $\mathrm{Na}$. The weight loss $\left(=\mathrm{SiO}_{2}\right)$ by treating with $\mathrm{HF}$, after sulphuric acid treatment, was 75 percent.

The amounts of calcium silicate and calcium hydroxide used in the experiments were based on a liming trial of small soil samples. 1.4 grams of the silicate material were needed to obtain the same $\mathrm{pH}$ rise as $0.32 \mathrm{~g} \mathrm{Ca}(\mathrm{OH})_{2}$ per 200 grams of soil "A". These amounts correspond fairly well in total calcium content as well as in neutralizing effects. In addition, liming treatments corresponding to 16 tons $\mathrm{Ca}(\mathrm{OH})_{2}$ per hectare, with and without additional calcium silicate and boron, in $5 \mathrm{~kg}$ of borax per hectare, were included in the first year treatments. Furthermore, three levels of potassium, corresponding to 0,150 and $300 \mathrm{~kg}$ per hectare of $\mathrm{K}$ in potassium chloride, were combined with all liming treatments in the first two years.

The rates of lime and ca'cium silicate materials used, calcu'ated in tons per hectare, can be seen from the tables. In the first two years of the experimental 
period the following rates of $\mathrm{N}$ - and P-ferti izers were applied: $200 \mathrm{~kg} \mathrm{~N}$ per hectare in ammonium nitrate, $60 \mathrm{~kg} \mathrm{P}$ per hectare in monocalcium dihydrogen phosphate.

In the 3 rd year and through to the 5 th year, the experiment (soil "An) was carried out using the same quantity of $\mathrm{K}$ for all pots $(150 \mathrm{~kg} \mathrm{~K}$ in potassium chloride $+150 \mathrm{~kg} \mathrm{~K}$ in potassium sulphate per hectare). The nitrogen treatment was $200 \mathrm{~kg} \mathrm{~N}$ per hectare per year, given in calcium nitrate, and the phosphorus rates were $50 \mathrm{~kg} \mathrm{P}$, calculated on a hectare basis.

Two-rowed spring barley, variety Herta, was sown in May and harvested when ripe. The number of plants was regulated by thining to give 14 plants per pot.

Chemical soil and plant analysis was carried out according to standard methods. The $\mathrm{SiO}_{2}$ content of the plant materials refers to the weight loss by $\mathrm{HF}$ treatments. Physical soil analysis included dry sieving and soil aggregate stability measurements using artificial rainfall (NJøs 1967).

\section{Results and discussion.}

Dry matter yields of barley grain and straw are shown in Tables $1-4$. Applications of 14 tons per hectare of the Ca-silicate material and of 3.2 tons of $\mathrm{Ca}(\mathrm{OH})_{2}$ gave the same soil $\mathrm{pH}$ value throughout the experimental period. Ca-silicate, in addition to a large quantity of calcium hydroxide, neither raised the $\mathrm{pH}$ nor markedly increased the soluble calcium in the soil extracts (Table 5). Thus, it can be concluded that the Ca-silicate applications resulted in significantly higher yields, over and above the effect of $\mathrm{Ca}$-silicate as a liming material. The straw yields increased somewhat more than the grain yields after silicate treatments. However, the increased $\mathrm{SiO}_{2}$ content of the straw accounts for roughly 20 percent of the straw yield increases.

Table 1. Dry matter barley yields, 1st and 2nd exp. year.

\begin{tabular}{|c|c|c|c|c|c|c|c|c|c|}
\hline \multicolumn{4}{|c|}{ First year treatments } & \multicolumn{3}{|c|}{ lst exp. year } & \multicolumn{3}{|c|}{ 2nd exp. year } \\
\hline & & $\begin{array}{c}\mathrm{Ca}(\mathrm{OH})_{2} \\
\text { tons/ha }\end{array}$ & $\begin{array}{c}\text { Ca-silicate } \\
\text { tons/ha }\end{array}$ & $\begin{array}{c}\mathrm{pH} \\
\text { of soil }\end{array}$ & $\begin{array}{l}\text { Grain } \\
\text { g/pot }\end{array}$ & $\begin{array}{l}\text { Straw } \\
\text { g/pot }\end{array}$ & $\begin{array}{c}\mathrm{pH} \\
\text { of soil }\end{array}$ & $\begin{array}{l}\text { Grain } \\
\text { g/pot }\end{array}$ & $\begin{array}{l}\text { Straw } \\
\text { g/pot }\end{array}$ \\
\hline & & 0 & 0 & 5.15 & 6.5 & 7.5 & & & \\
\hline & & 3.2 & 0 & 6.35 & 22.1 & 25.6 & 6.1 & 18.3 & 23.1 \\
\hline \multirow[t]{4}{*}{ Soil } & $A, \ldots . .$. & 0 & 14 & 6.35 & 26.0 & 33.1 & 6.1 & 25.9 & 30.3 \\
\hline & & 16 & 0 & $7.4-8.1$ & 34.3 & 43.3 & 8.1 & 32.6 & 38.7 \\
\hline & & 16 & 14 & $7.4-8.1$ & 37.7 & 47.3 & 8.1 & 37.9 & 41.4 \\
\hline & & 0 & 0 & 5.9 & 25.5 & 31.3 & 5.7 & 23.6 & 28.4 \\
\hline \multirow[t]{3}{*}{ Soil } & ${ }^{B}, \ldots . .$. & 2.4 & 0 & 6.5 & 25.8 & 31.9 & 6.3 & 25.0 & 29.8 \\
\hline & & 0 & 14 & 6.6 & 26.9 & 39.0 & 6.3 & 32.1 & 34.2 \\
\hline & & 16 & 0 & $7.4-8.2$ & 26.9 & 37.8 & 8.1 & 34.9 & 39.1 \\
\hline LSD & $\mathrm{g} / \mathrm{pot}$ & & & & 2.6 & 2.4 & & 3.7 & 2.7 \\
\hline
\end{tabular}


Table 2. Dry matter barley yields. 3rd to 5 th exp. years. Soil,$A$.

\begin{tabular}{|c|c|c|c|c|c|c|c|c|}
\hline \multicolumn{2}{|c|}{ First year tratments } & \multicolumn{3}{|c|}{ 3rd exp. year } & \multicolumn{2}{|c|}{ 4th exp. year } & \multicolumn{2}{|c|}{ 5th exp. year } \\
\hline $\begin{array}{c}\mathrm{Ca}(\mathrm{OH})_{2} \\
\text { tons/ha }\end{array}$ & $\begin{array}{c}\text { Ca-silicate } \\
\text { tons/ha }\end{array}$ & $\begin{array}{l}\mathrm{pH} \text { of soil } \\
3-5 \text { yrs. }\end{array}$ & $\begin{array}{l}\text { Grain } \\
\text { g/pot }\end{array}$ & $\begin{array}{l}\text { Straw } \\
\text { g/pot }\end{array}$ & $\begin{array}{l}\text { Grain } \\
\text { g/pot }\end{array}$ & $\begin{array}{l}\text { Straw } \\
\text { g/pot }\end{array}$ & $\begin{array}{l}\text { Grain } \\
\text { g/pot }\end{array}$ & $\begin{array}{l}\text { Straw } \\
\text { g/pot }\end{array}$ \\
\hline 3.2 & 0 & 6.2 & 15.9 & 18.4 & 21.1 & 19.0 & 22.3 & 24.4 \\
\hline 0 & 14 & 6.2 & 24.9 & 25.0 & 21.2 & 22.2 & 24.0 & 25.5 \\
\hline 16 & 0 & 8.1 & 29.8 & 30.1 & 24.2 & 23.4 & 25.1 & 28.4 \\
\hline 16 & 14 & 8.1 & 33.6 & 36.7 & 24.9 & 27.0 & 27.3 & 30.1 \\
\hline LSD $g /$ pot & & & 4.7 & 2.2 & 2.0 & 2.0 & 1.6 & 1.7 \\
\hline
\end{tabular}

$\mathrm{LSD}=$ Least significant difference

Table 3. Potassium effects on grain yields in lst exp. year. Soil *A*.

\begin{tabular}{|c|c|c|c|c|c|}
\hline \multirow[b]{2}{*}{$\mathrm{Kg} \mathrm{K} / \mathrm{ha}$ in $\mathrm{KCl}$} & \multicolumn{2}{|c|}{$\begin{array}{c}\text { Low-lime level } \\
\text { pH } 6.35\end{array}$} & & \multicolumn{2}{|c|}{$\begin{array}{c}\text { High-lime level } \\
\text { pH } 8\end{array}$} \\
\hline & 150 & 300 & & 150 & 300 \\
\hline Without silicate ....................... & 22.8 & 23.6 & & 35.8 & 30.4 \\
\hline With 14 t Ca-silicate/ha ............. & 25.9 & 27.3 & & 41.9 & 30.9 \\
\hline Without boron ......................... & & & & 38.8 & 30.9 \\
\hline With $5 \mathrm{~kg}$ borax/ha ................. & & & & 38.9 & 30.4 \\
\hline With borax + silicate $. . . \ldots \ldots \ldots . . .$. & & & & 40.4 & 30.7 \\
\hline Without magnesium ................ & 22.8 & 23.6 & & 35.8 & 30.4 \\
\hline With $\left.100 \mathrm{~kg} \mathrm{Mg}^{1}\right) / \mathrm{ha} . . . \ldots \ldots \ldots . . . . .$. & 23.5 & 23.3 & & 32.7 & 26.9 \\
\hline LSD g/pot ........................... & & & 3.6 & & \\
\hline
\end{tabular}

1) In $\mathrm{MgSO}_{4} 7 \mathrm{H}_{2} \mathrm{O}$

The effects of both lime and silicate were also significant in the 4 th and 5 th years after application, although the yield increases were much smaller than in the previous years.

The absorption of silica was greatest in the first year. The silica content of straw dry matter increased from less than 1 percent to $5-7$ percent as a result of the silica application. From the 2 nd to the 5 th year, the silica content of the straw was stabilized in the range of $2-4$ percent after the initial silica treatment.

The barley plant in the silica treated soil showed a vigorous growth. The most distinctive features of these plants, however, were the silica deposits which could be distinguished as "rough leaf surfaces."

Table 3 shows that a large quantity of potassium chloride markedly decreased the barley grain yields at the high lime level. Straw yields, not reported, showed a small increase with the same treatment. Further, the table shows that neither silicate and boron nor magnesium sulphate counteracted the potassium over-liming injury. Manganese deficiency can also be ruled out as a cause of the yield decrease in this case. Magnesium deficiency symptoms 
appeared in the barley leaves at the high-lime level, especially at the highest K-rate. A magnesium application of 1 ton magnesium sulphate per hectare did not entirely eliminate these symptoms. Over-liming produced a wide $\mathrm{Ca}: \mathrm{Mg}$ concentration ratio in the soil solution (Table 5). Nevertheless, the causes of the unfavorable effects of the high lime - high potassium treatment in this experiment remain unsolved.

Table 4. Boron effects on grain yields in 2nd exp. year. Soil "A».

\begin{tabular}{|c|c|c|c|c|c|}
\hline \multirow[b]{2}{*}{ Kg borax/ha } & \multicolumn{2}{|c|}{ Low-lime level } & & \multicolumn{2}{|c|}{ High-lime level } \\
\hline & 0 & 10 & & 0 & 10 \\
\hline Without silicate $\ldots \ldots \ldots \ldots \ldots \ldots \ldots \ldots . \ldots . \ldots . \ldots$ & 22.5 & 14.1 & & 31.0 & 34.1 \\
\hline With 14 t Ca-silicate/ha ........... & 28.0 & 23.9 & & 38.5 & 37.4 \\
\hline
\end{tabular}

In the 2nd experimental year, the rate of borax was raised from 5 to $10 \mathrm{~kg}$ per hectare and boron was applied also in the low-lime series. The borax application caused yield depression at $\mathrm{pH} 6.1$ as shown in Table 4. The interaction of boron $\mathrm{x}$ lime level in crop yield figures is significant, whereas no clear interactions were found for silica $\mathrm{x}$ boron, or silica $\mathrm{x}$ boron $\mathrm{x}$ lime level. No detrimental effects derived from the high rate of potassium applications in the 2nd year and these figures'are, therefore, not given.

All grain and straw crops were analyzed for the following elements: $\mathrm{Ca}, \mathrm{K}$, $\mathrm{Na}, \mathrm{P}$ and $\mathrm{SiO}_{2}$. In the first year, $\mathrm{Mg}$-determination was also included.

In order to get more information about the effects on the soil of the treatments, samples of soil solution were extracted during the growing season of the first experimental year. Destilled water was applied to full saturation in the evening and extraction was carried out next morning by means of suction through glasswool filter equipment placed in each pot (UHLEN 1959). Unfortunately, $\mathrm{SiO}$ determination was not conducted on the soil extracts. Table 5 gives the quantity of phosphorus, calcium, magnesium and potassium, in mg per litre of extract. The total water content of each pot at the start of extraction was $\mathbf{5 0}$ percent by weight, and the amount extracted was $200-400$ millilitres per pot.

Table 5. Parts per million in 2: 1 soil extract. Samples taken at tillering stage in 1st exp year. Soil As.

\begin{tabular}{|c|c|c|c|c|}
\hline \multirow[b]{2}{*}{ Ca-silicate, tons/ha } & \multicolumn{2}{|c|}{$\begin{array}{l}\text { Low lime level } \\
\text { pH } 6.35\end{array}$} & \multicolumn{2}{|c|}{$\begin{array}{c}\text { High lime level } \\
\text { pH } 7.4\end{array}$} \\
\hline & 0 & 14 & 0 & 14 \\
\hline Phosphorus ....... & 0.09 & 0.12 & 0.19 & 0.22 \\
\hline 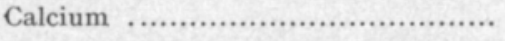 & 647 & 663 & 825 & 857 \\
\hline Magnesium (without $\mathrm{Mg}$ treatment) & 42 & 40 & 8 & 9 \\
\hline - (with Mg treatment) .... & 81 & & 13 & \\
\hline Potassium $\quad 0 \mathrm{~kg} / \mathrm{ha} . \ldots \ldots \ldots \ldots \ldots . . . . . .$. & 4 & 5 & 8 & 8 \\
\hline 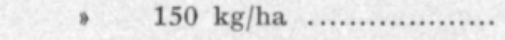 & 14 & 18 & 19 & 17 \\
\hline $300 \mathrm{~kg} / \mathrm{ha} . \ldots \ldots \ldots \ldots \ldots \ldots . . . . . .$. & 25 & 34 & 27 & 26 \\
\hline
\end{tabular}


Application of Ca-silicate increased the phosphorus concentration in the soil extracts. In contrast to this result, the phosphorus concentration of the barley crops was not increased (Table 6). As a consequence of the high yield per pot, the total amount of $\mathrm{P}$ and $\mathrm{K}$ in the five year cropping period equals roughly the amount applied in fertilizers. The fact that the available amount of the nutrients is diluted in a larger crop explains the lower concentrations, especially of potassium, after lime and silicate applications. At the high-lime level, the silicate addition seemed to cause a reduction in the calcium and potassium absorption of the barley plants.

Table 6. Silica, phosphorus, calcium, and potassium in the barley crops. Soil As.

\begin{tabular}{|c|c|c|c|c|c|c|c|c|c|c|c|c|c|}
\hline \multirow{3}{*}{$\begin{array}{c}\mathrm{Ca}(\mathrm{OH})_{2} \\
\text { tons/ha }\end{array}$} & \multirow{3}{*}{$\begin{array}{l}\text { Ca- } \\
\text { silicate } \\
\text { tons/ha }\end{array}$} & \multicolumn{8}{|c|}{ Percentages of dry matter. 5 year mean } & \multirow{2}{*}{\multicolumn{4}{|c|}{$\begin{array}{l}\text { Total over } 5 \\
\text { years, g/pot }\end{array}$}} \\
\hline & & \multicolumn{4}{|c|}{ Grain } & \multicolumn{4}{|c|}{ Straw } & & & & \\
\hline & & $\mathrm{SiO}_{2}$ & $\mathrm{P}$ & $\mathrm{Ca}$ & K & $\mathrm{SiO}_{2}$ & $\mathbf{P}$ & $\mathrm{Ca}$ & $\mathrm{K}$ & $\mathrm{SiO}_{2}$ & $\mathbf{P}$ & $\mathrm{Ca}$ & K \\
\hline 3.2 & 0 & 0.30 & 0.31 & 0.056 & 0.55 & 1.21 & 0.057 & 0.74 & 2.57 & 1.6 & 0.37 & 0.88 & 3.42 \\
\hline 0 & 14 & 0.61 & 0.28 & 0.051 & 0.54 & 3.99 & 0.044 & 0.62 & 2.11 & 6.2 & 0.40 & 0.91 & 3.56 \\
\hline 16 & 0 & 0.34 & 0.28 & 0.058 & 0.52 & 1.13 & 0.043 & 0.91 & 1.83 & 2.4 & 0.47 & 1.57 & 3.78 \\
\hline 16 & 14 & 0.65 & 0.29 & 0.055 & 0.51 & 3.49 & 0.043 & 0.77 & 1.45 & 7.4 & 0.54 & 1.49 & 3.51 \\
\hline
\end{tabular}

Table 7. Percent of silica in the dry matter yields in relation to potassium and lime levels. Averages for the 1st and 2nd year, soil $A$, and $\left.{ }^{*} B \vartheta^{1}\right)$.

\begin{tabular}{|c|c|c|c|c|c|c|}
\hline \multirow[b]{2}{*}{$\mathrm{Kg} \mathrm{K}$ in $\mathrm{KCl}$} & \multicolumn{3}{|c|}{ Low lime level } & \multicolumn{3}{|c|}{ High lime level } \\
\hline & 0 & 150 & 300 & 0 & 150 & 300 \\
\hline Grain: & & \multicolumn{5}{|c|}{$\mathrm{SiO}_{2}$, percent of dry matter } \\
\hline Without silicate .............. & 0.23 & 0.23 & 0.22 & 0.18 & 0.22 & 0.31 \\
\hline With 14 t Ca-silicate/ha ......................... & 0.61 & 0.63 & 0.66 & 0.38 & 0.62 & 0.80 \\
\hline \multicolumn{7}{|l|}{ Straw: } \\
\hline 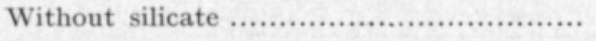 & 1.0 & 0.9 & 1.0 & 0.7 & 0.8 & 0.9 \\
\hline With $14 \mathrm{t} \mathrm{Ca-silicate/ha}$........................ & 5.1 & 5.0 & 4.8 & 2.0 & 3.3 & 4.1 \\
\hline Straw: & . & \multicolumn{5}{|c|}{$K$, percent of dry matter } \\
\hline 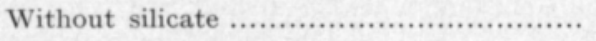 & 0.58 & 1.58 & 2.27 & 0.30 & 1.01 & 1.71 \\
\hline With 14 t Ca-silicate/ha ......................... & 0.47 & 1.21 & 1.78 & 0.21 & 0.76 & 1.27 \\
\hline
\end{tabular}

1) The high-lime with silica treatment was not included in the experiment on soil $*$ B.

The potassium treatments, which varied only in the first two experimental years, had a marked influence upon the silicon uptake at high-lime levels. At the low-lime level, this effect of potassium on silica absorption was not detected (Table 7). At a zero level of potassium, the silica content of both grain and straw was drastically reduced. Furthermore, the highest rate of potassium application increased the silica uptake considerably when compared to that of a moderate potassium application. In this connection, however, it 
should be noted that the straw yield increases with the higher rate were rather modest both years, and a negative response in grain yields with the above potassium treatment occurred in the first year. The effect of $\mathrm{K}$ upon the silicon uptake at the high-lime level did occur both years and in both soil series. The question arises therefore, whether or not a direct potassium-silicon absorption synergism exists. The increased uptake of silicon could be a result of higher transpiration rates brought about by the potassium treatment. According to AMBerger (1968), however, a good supply of potassium should decrease rather than increase the water consumed per unit of dry matter produced. Potassium ions are known to play an important role in stomata opening in the light (FISCHER 1971). Thus, transpiration through stomata may be expected to increase from plants well supplied with potassium. Further studies of a possible potassium-silicon interaction at high soil $\mathrm{pH}$ values are in fact needed.

At the end of the five year cropping period, some chemical and physical determinations were carried out on soil samples (Table 8 and Table 9). By using the ammonium lactate acetate method according to EGNER, somewhat less $\mathrm{K}$ and $\mathrm{Mg}$ were extracted from the high-lime soil than from the soil with $\mathrm{pH}$ 6.1-6.3. The differences obtained in the Ca-AL-values ( exchangeable $\mathrm{Ca}$ ) are in accord with the amounts of $\mathrm{Ca}$ applied. Ca-silicate had increased the readily soluble phosphorus (P-AL) in the high-lime soil only.

Table 8. Soil analysis data at the end of five years of cropping.

\begin{tabular}{|c|c|c|c|c|c|}
\hline \multicolumn{2}{|c|}{ First year treatments } & \multicolumn{4}{|c|}{$\begin{array}{l}\mathrm{Mg} \text { per } 100 \mathrm{~g} \text { dry soil acc. to } \\
\text { Egnérs ammonium lactate acetate method }\end{array}$} \\
\hline $\begin{array}{l}\mathrm{Ca}(\mathrm{OH})_{2} \\
\text { tons/ha }\end{array}$ & $\begin{array}{l}\text { Ca-silicate } \\
\text { tons/ha }\end{array}$ & $\mathrm{Ca}-\mathrm{AL}$ & K-AL & Mg-AL & P-AL \\
\hline 3.2 & 0 & 172 & 8.1 & 6.8 & 3.7 \\
\hline 0 & 14 & 181 & 8.9 & 6.7 & 3.7 \\
\hline 16 & 0 & 453 & 5.3 & 2.4 & 8.4 \\
\hline 16 & 14 & 549 & 5.8 & 3.2 & 11.0 \\
\hline
\end{tabular}

Table 9. Soil aggregate size distribution and aggregate stability (artificial rainfall) at the end of five years of cropping.

\begin{tabular}{|c|c|c|c|c|c|c|c|}
\hline \multicolumn{2}{|c|}{ First year treatments } & \multicolumn{4}{|c|}{ Aggregate size distribution percentages } & \multicolumn{2}{|c|}{$\begin{array}{l}\text { Percent of aggre- } \\
\text { gates water stable }\end{array}$} \\
\hline $\begin{array}{c}\mathrm{Ca}(\mathrm{OH})_{2} \\
\text { tons/ha }\end{array}$ & $\begin{array}{c}\text { Ca-silicate } \\
\text { tons/ha }\end{array}$ & $<6 \mathrm{~mm}$ & $6-2 \mathrm{~mm}$ & $2-0.6 \mathrm{~mm}$ & $<0.6 \mathrm{~mm}$ & $6-2 \mathrm{~mm}$ & $2-0.6 \mathrm{~mm}$ \\
\hline 3.2 & 0 & 7.4 & 11.0 & 28.8 & 52.8 & 50 & 52 \\
\hline 0 & 14 & 6.2 & 10.9 & 29.8 & 53.1 & 61 & 63 \\
\hline 16 & 0 & 4.1 & 11.0 & 36.1 & 48.8 & 70 & 74 \\
\hline 16 & 14 & 3.2 & 10.7 & 37.8 & 48.3 & 79 & 78 \\
\hline LSD & & 1.6 & 1.7 & 1.4 & 3.6 & 5.9 & 3.0 \\
\hline
\end{tabular}


Excess liming treatment influenced the soil aggregation, giving more aggregates in the range $2-0.6 \mathrm{~mm}$ and less fine soil particles $(<0.6 \mathrm{~mm}$ ) and particles larger than $6 \mathrm{~mm}$ (clods) than existed with the low-lime soil. Ca-silicate seems to have had only a moderate effect upon the particle size distribution if compared to that of lime. The determination of the stability of the soil aggregates, $6-2 \mathrm{~mm}$ and $2-0.6 \mathrm{~mm}$, in artificial rainfall $(30 \mathrm{~mm}$ in $3 \mathrm{~min}$ ) yielded significant differences, resulting from both the lime and the silica treatments given five years previously. In conformity with crop yield behaviour, we can again call attention to the specific effect of silicate, over and above that of the lime or calcium applied. It was not proved, however, that the changes brought about in the physical conditions of the soil are the factors responsible for the positive yield effects of silicate applications.

The results of the experiment described in this paper are not at variance with the hypothesis that silicon plays a rather passive role in plant nutrition, although silica materials can lead to yield increases and improvement in both chemical and physical soil conditions.

\section{REFERENCES}

Amberger, A. 1968. Functions of potash in the plant. Potash Review 3/27: 1-5.

Arnon, D. I. 1951. Growth and function as criteria in determining the essential nature of inorganic nutrients. In Mineral Nutrition of Plants by E. Truog. Univ. of Wisc. Press. p. 313-341.

Ayres, A. S. 1966. Calcium silicate slag as a growth stimulant for sugarcane on low-silicone soils. Soil Sci. 101: 216-227.

Barber, D. A. \& Shone, M. G. T. 1966. The absorption of silica from aqueous solutions by plants. J. Exptl. Botany 17: 569-578.

Berggren, B. 1965. Strukturförändringar hos en silikatbehandlad lerjord. Specialmedd. 13, Jordbrukstekn. Inst. Uppsala 71 p.

Bowen, J. E. 1972. Manganese-siliocon interaction and its effect on growth of sudan grass. Plant and Soil 37:577-588.

Deinum, B. \& VAn Soest, P. J. 1969. Prediction of forage digestibility from some laboratorie procedures. Neth. J. Agric. Sci. 17: 119-127.

D'Hoore, J. \& Coulter, J. K. 1972. Soil silicon and plant nutrition. Soils of the Humic Tropics Nat. Acad. of Sciences Wash. D. C. p. 163-173.

Durt, A. K. 1947. The effect of water-soluble potassium silicate and various other treatments on soil structure and crop growth. Soil Sci. Soc. Amer. Proc. 12: 497-501.

FIdanovskı, F. 1968. Silicium, ein für die Pflanzen snützliches» Element. Z. Pfl.ernähr. und Bodenk. 120: 191-207.

Fischer, R. A. 1971. Role of potassium in stomatal opening in the leaf of Vicia faba. Plant Physiol. 47: 555-558.

GaArder, T. 1930. Die Bindung der Phosphorsäure im Erdboden. Medd. nr. 14 fra Vestl. forstl. Forsøksstasjon, p. 1-140.

Hunter, A. S. 1965. Effects of silicate on uptake of phosphorus from soils by four crops. Soil Sci. 100: $391-396$.

Jones, L. H. P. \& Handreck, K. A. 1967. Silica in soils, plants and animals. Adv. in Agron. 19: $107-149$.

- - Mrlne, A. A. \& Wadham, S. M. 1963. Studies of silica in the oat plant. II Distribution of the silica in the plant. Plant and Soil 18: 358-371.

Lanning, F. C., Ponnatya, B. W. X. \& Crumpton, C. F. 1958. The chemical nature of silica in plants. Plant Pysiol. 33: 339-343. 
Lewin, J. \& Rermann, B. E. F. 1969. Silicon and plant growth. Ann. Rev. of Plant Physiol. 20: $289-304$.

McKeague, J. A. \& Cline, M. G. 1963. Silica in soils. Adv, in Agron. 15: 339-396.

Меsнеснок, B. 1968. Om startgjødsling ved skogkultur på myr. Meddr. norske Skogfors. Ves. 25: $1-140$.

Mrtsu1, S. \& ТАкатон, H. 1963. Nutritional study of silicon in graminaceous crops. Soil Sci. Plant Nutr. 9:49-58.

NJes, A. 1967. In West-European methods for soil structure determination. IV p. 43 and VI p. 53.) Ed. by West European Working Group on Soil Structure of Int. Soil Sci. Soc. Ghent.

Plúcknetr, D. L. 1972. The use of soluble silicates in Hawaiian agriculture. Univ. of Queensland Pap. Vol. I, No. 6, St. Lucia, p. 202-223.

Sемв, G. 1943. Undersøkelser over fosforsyrens oppløselighet og binding i østnorske jordtyper. Meld. NLH 23: 1-145.

UHLEN, G. 1959. A technique for studying the dynamic behavior of the soil-plant system, with special reference to the effect of soil acidity and lime application. Tech. rep. Cornell Univ. $138 \mathrm{p}$.

Williams, D. E. \& Vlams, J. 1957. The effect of silicon on yield and manganese-54 uptake and distribution in the leaves of barley plants grown in culture solutions. Plant Physiol. 32: 404-409.

Yoshida, S., Оhnishi, Y. \& Krtagishi, K. 1959. Role of silicon in rice nutrition. Soil Sci. Plant. Nutr. 5: 127-133.

\title{
Selostus $\left.^{1}\right)$
}

\section{Kalsiumsilikaatin vaikutus ohraan astiakokeessa}

\author{
GOTFRED UhLEN \\ Norjan maatalouskorkeakoulu
}

Viisivuotisessa astiakokeessa, joka suoritettiin kasvihuoneessa, verrattiin $14 \mathrm{t} / \mathrm{ha}$ kalsiumsilikaattiannosta (12\% Ca) ekvivalenttiseen $3.2 \mathrm{t} /$ ha kalsiumhydroksidiannokseen hiuemaalla $\left(* A\right.$ »). Kokeeseen kuului myös hyvin runsas kalkitus, $16 \mathrm{t} / \mathrm{ha} \mathrm{Ca}(\mathrm{OH})_{2}$, sekä ilman $14 \mathrm{t} / \mathrm{ha}$ kalsiumsilikaatin lisäystä että sen kera. Toisella hiuemaalla (*B») suoritettiin kaksivuotinen silikaatinlisäyksen ja kalkituksen vaikutusta selvittävä koe.

Silikaatin lisäys suurensi ohran jyvä- ja olkisatoa. Vaikutus oli tasaisesti suurempi kuin ekvivalenttisella $\mathrm{Ca}(\mathrm{OH})_{2}$-määrällä. Silikaatin lisäys ei ehkäissyt hyvin runsaiden kalkituksen ja kaliumlannoituksen satoa vähentävää vaikutusta eikä sadonvähennystä, jonka boorilannoitus aiheutti vähän kalkitussa maassa $(\bullet A$,$) . Silikaatin ja kalkin aiheuttamat sadonlisäykset olivat$ vielä neljäntenä ja viidentenä vuonna käsittelyn jälkeen merkitseviä joskin pieniä verrattuna kolmena ensimmäisenä vuonna todettuihin sadonlisäyksiin.

Ohran jyvien ja olkien piidioksidipitoisuus kohosi huomattavasti silikaatinlisäyksen jälkeen. Esim. ensimmäisenä vuonna olkien kuiva-aineen $\mathrm{SiO}_{2}$-pitoisuus nousi vajaasta prosentista 7 prosenttiin. Silikaattikäsittelyillä tai runsaalla $\mathrm{SiO}_{2}: \mathrm{n}$ otolla ei ilmeisesti ollut suoranaista vaikutusta ohrasadon fosforin, kalsiumin, kaliumin tai magnesiumin pitoisuuteen, vaikka silikaatti näytti parantavan maan fosforin käyttökelpoisuutta.

Runsaasti kalkituissa astioissa kaliumlannoitus kohotti ohran olkien ja jyvien piidioksidin pitoisuuden suunnilleen kaksinkertaiseksi kahtena ensimmäisenä koevuonna. Vähän kalkituissa maissa $(* A, j a * B *)$ vastaavaa vaikutusta ei esiintynyt.

Viiden koevuoden jälkeen kalkin ja silikaatin todettiin vaikuttaneen maan murukoostumukseen ja parantaneen huomattavasti murujen kestävyyttä.

1) Selostuksen laatinut A. Jaakkola. 